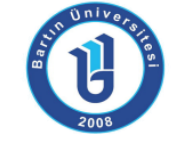

ISSN: 1308-7177

\title{
İ̧̧ Birlikli Yazma Etkinliklerinin Sınıf Öğretmeni Adaylarının Yazma Becerilerine ve Yazmaya Illişkin Tutumlarına Etkisi
}

Özge ERDOĞAN; Yrd. Doç. Dr., Karadeniz Teknik Üniversitesi Fatih Eğitim Fakültesi, erdoganozge.edu@gmail.com

Öz: Bu araştırmanın amacı, iş birlikli yazma etkinliklerinin sınıf öğretmeni adaylarının yazma becerilerine ve yazmaya ilişkin tutumlarına etkisini belirlemektir. Araştırmada "tek grup ön test-son test deneysel desen" kullanılmıştır. Araştırmaya Karadeniz Teknik Üniversitesi Sınıf Öğretmenliği Ana Bilim Dalında 2. sınıfta öğrenim görmekte olan 28 öğretmen adayı katılmıştır. Araştırmada sınıf öğretmeni adaylarına iş birlikli yazma etkinlikleri yaptırılmıştır. Adayların, uygulama öncesinde ve sonrasında yazma becerilerini belirlemek için "Yazma Becerisi Değerlendirme Formu" ve yazmaya ilişkin tutumlarını belirlemek için "Yazma Tutum Ölçeği" kullanılmıştır. Araştırmada elde edilen sonuçlar, iş birlikli yazma etkinliklerinin sınıf öğretmeni adaylarının yazma becerilerini geliştirdiğini ve yazmaya ilişkin tutumlarını olumlu yönde etkilediğini ortaya koymaktadır.

Anahtar Kelimeler: iş birlikli yazma, yazma, yazmaya ilişkin tutum, sınıf öğretmeni adayı

\section{The Effects of Collaborative Writing Activities on Pre- Service Classroom Teachers' Writing and Attitude towards Writing}

\begin{abstract}
The aim of the study is to identify the effects of the collaborative writing activities on the pre-service classroom teachers' attitudes concerning the written expression skills and writing. In the study the design of single group, pretest and post test was employed. The participants of the study were 28 student teachers who were attending second grade at the classroom teaching branch of the educational sciences faculty at Karadeniz Technical University. In the study several collaborative writing activities were carried out with the participants. In order to determine the writing skills of the participants before and after the study an evaluation form of writing skills was administered to them. In order to determine their attitudes towards writing before and after the study the scale of writing attitudes was used. The findings of the study showed that collaborative writing activities improve the participants' writing skills and their attitudes towards writing.
\end{abstract}

Key Words: collaborative writing, writing, attitudes towards writing, pre-service classroom teachers 


\section{GíRiş}

Öğrencileri bilişsel ve sosyal anlamda aktif, girişimci, problem çözebilen, eleştirel ve yaratıcı düşünebilen bireyler olarak yetiştirmede, yazma becerisinin gelişimi oldukça önemli bir rol oynar. Yazma becerisi yeterince gelişmiş bir öğrenci, kendisini sadece yazılı olarak değil sözel anlamda da doğru bir şekilde ifade edebilir. Bunun yanı sıra anlama becerilerini kullanarak etkili bir iletişim kurar. Bu bağlamda yazma becerisinin gelişimi etkileşimli bir süreçtir.

Yazma, öğrencinin düşünmesine, kendi düşünceleri arasında ilişki kurmasına ve yeni düşünceler üretmesine olanak tanır (Kahn ve Holody, 2012). Bu durum öğrencilerin ne bildiklerinin farkında olmalarına başka bir deyişle kendi bilişsel süreçlerini fark etmelerine ihtiyaçları olduğunu gösterir. Yazma, beyinde yapılandırılmış bilgilerin yazıya dökülmesidir. Yazma süreci için sıralama, sınıflama, ilişki kurma, eleştirme, tahmin etme gibi çeşitli zihinsel işlemler gerekmektedir (Güneş, 2007). Olinghouse ve Santangelo'ya (2010) göre yazma, farklı becerilerin ve süreçlerin koordinasyonunu gerektiren karmaşık bir görevdir. Bu nedenle en zor kazanılan ve öğrencilerin en çok zorlandıkları dil becerisidir.

De Smedt ve Van Keer'e (2014) göre yazma becerisinin gelişiminde, toplumda bireylerin birbirleri ile kurdukları diyaloglar ve paylaşımlar son derece etkin bir rol oynar. Çünkü sosyal bir varlık olan birey, çevresini gözlemler ve gözlemlerini beyninde yapılandırır. Beyinde yapılandırılan bu bilgiler de yazma sürecinde kullanılır. Başka bir deyişle yazma; gözlem yapma, yapılan gözlemleri analiz etme ve bunları düzenleyerek düşüncelerini yazıya aktarmayı gerektiren sosyal bir süreçtir (Nauman 2007; Sharples, 2003).

Yazma, başlı başına sosyal bir etkinliktir. Yazma, her ne kadar bireysel olarak bir etkinlik olarak nitelendirilse de son yıllarda öğrencilerin iş birliği ile çalıştığı ve sürece birlikte katıldıkları sosyal bir etkinlik olarak tanımlanmaktadır (Lin ve Maarof, 2013; Topping, Nixon, Sutherland ve Yarrow, 2000; Yang, 2014; Wigglesworth ve Storch, 2012). Buradan hareketle iş birlikli yapılan yazma etkinliklerine yönelik alan yazında birçok çalışma yer almaktadır (Anılan, Akkuş ve Acar, 2009; Dyson, 1995, Lin ve Maarof, 2013; Maden, 2011; Fung 2010; Karsbaek, 2011; Lundstrom ve Baker, 2009; Miell ve Littleton, 2008; Vass, 2007).

İş birlikli yazma, öğrencilerin bir konu hakkında küçük gruplar halinde birlikte çalışarak bir metin oluşturmasıdır (Güneş, 2007). Öğrencilerin ikişerli ya da gruplar halinde çalışarak birlikte bir yazılı ürün ortaya koydukları bir süreçtir. Bu süreçte grup üyeleri, tüm yazma basamaklarında hep birlikte çalışırlar. Ortaya çıkacak metin için yazarlığı ve sorumluluğu paylaşırlar (Dobao ve Blum, 2013). Başka bir deyişle ortak bir ürün ortaya koymak için grup üyeleri kendi fikirlerini tartışır, konuşur ve sonunda eşgüdüm sağlarlar. Kendi aralarındaki uyum ve koordinasyon; ortak bir karara varma, grup üyelerinden gelen değişik fikirleri yönetme ve sonuca ulaşma konusunda grup üyelerine yol gösterir (Lowry, Curtis ve Lowry, 2004).

Fletcher ve Portalupi'ye (2001) göre iş birlikli yazma, öğrencilerin kendilerine güvenerek daha nitelikli yazılar yazmaları için etkili bir stratejidir. Yazma eylemi sırasında zihindeki bilgileri düzenleme, düşünceleri istenilen bir şekilde sıraya dizme, yazım hatalarını kontrol etme, yazılan yazıyı tekrar okuma ve yazıyı destekleyecek örnekler bulma/ekleme gibi birçok işlem gerçekleştirilir. Bu zihinsel işlemler tek başına bir öğrenciye zor gelebilir ya da üstesinden gelmek için uzun çaba harcamasını gerektirebilir. Ancak iş birlikli yazma, öğrencilerin tüm bu becerilerin üstesinden gelebilmeleri için onlara güvenilir bir ortam sağlar. Bu öz güven sayesinde kendilerini bir yazar olarak görebilirler ve yazma sürecine yönelik olumlu tutum geliştirebilirler. 
Swain'e (2000) göre iş birliği sırasında kurulan diyaloglar ile öğrencilerin sosyal becerileri, yaratıcı düşünme eğilimleri ve bilişsel gelişimleri olumlu yönde etkilenir. Ancak bireysel yapılan yazma çalışmalarında ise bu etkileşim ortamı olmadığı için öğrenciler daha çok öğretmenin çizdiği sınırlar içinde kalır. İş birlikli yazma sırasında, öğretmenin sınıfa hâkim olduğu geleneksel yazma etkinliklerinden uzaklaşılır ve öğrencilerin birbirleriyle etkileşimli olduğu bir öğrenme ve öğretme ortamı ortaya çıkar (Lin ve Maarof, 2013). Bu etkileşimli grup çalışması sırasında ortaya koymaya çalıştıkları yazı için kendi dil becerilerini sürece aktararak yazılarını birlikte yapılandırırlar. Birbirlerinin deneyimlerinden ve dil becerilerinden yararlanarak aynı ifadeyi farklı yollarla ifade etmeyi öğrenirler. Yang'a (2014) göre grup üyelerinin dil becerileri konusundaki yeterlikleri ve birbirleri ile iletişimleri iş birlikli yazmanın başarısını yordayan etkenler arasında yer alır.

Her öğrencinin başarılı olduğu yönler birbirinden farklıdır. İ̧̧ birlikli çalışma sırasında her bir grup üyesi kendi güçlü yönlerini ortaya koyar ve bu durum bireysel olarak yaptıkları çalışmalara göre daha nitelikli çalışmalar çıkmasına yardımcı olur. Çünkü iş birliği süresince öğrenciler birbirlerinin düşünme süreçlerini gözlemlerler ve farklı düşünme yolları geliştirirler (Ferguson-Patrick, 2007). İ̧̧ birlikli yazma çalışmaları üzerine yapılan çalışmalar; iş birliğinin gruplardaki kişiler arasında duygu ve düşüncelerin rahatlıkla ifade edilmesinde (Topping, Smith, Swanson ve Elliot, 2000), anlama becerilerinin gelişiminde (Phielix, Prins ve Kirschner, 2010; Storch, 2005) ve daha nitelikli yazılı anlatım ürünlerinin ortaya koyulmasında (Ferguson-Patrick, 2007; Swain, 2000; Yarrow ve Topping, 2001) etkili olduğunu ortaya koymuştur.

Yazma alanındaki birçok araştırmacı (Cutler ve Graham, 2008; Graham ve Sandmel, 2011; Graham, Berninger ve Abbott, 2012; Nauman, 2007) bireysel veya iş birlikli yapılan yazma etkinliklerini geleneksel ve süreç temelli olmak üzere iki ana kategoriye ayırır. Geleneksel yazma öğretiminde; öğrencilere verilen çalışma yapraklarında veya çalışma kitaplarında yönergesi belli olan, devamında herhangi bir çalışma yapılmayan, genellikle yazı için kısa yer ve zaman ayrılan yazma çalışmaları yapılır. Süreç temelli yazma öğretiminde ise yazma beş aşamadan oluşan bir süreç şeklinde ilerler (McCarthey ve Ro, 2011). Süreç temelli yazma; yazma öncesi, taslak yazma, gözden geçirme, düzenleme ve yayımlama aşamalarından oluşur. Yazma öncesi aşamada yazmaya bilişsel ve duyuşsal olarak hazırlık yapılır. Konu ile ilgili ön bilgiler harekete geçirilir. Taslak yazma aşamasında konu ile ilgili bir metin oluşturulmaya başlanır. Yazılan taslak, gözden geçirme aşamasında anlam bağlamında incelenir. Mekanik düzenlemeler de tamamlandıktan sonra yayımlama aşamasında ortaya koyulan yazılı ürünler paylaşılır (Kolb, Longest ve Jensen, 2013; Sundem, 2007; Bright, 2007; Muschla, 2006; Olive, 2004). Yazma sürecinin aşamalar ile ilerlemesi ve öğretmenlerin bu aşamaları öğrencilerle birlikte yürütmesi; öğrencilerin yazma sürecini benimsemelerini, içselleştirmelerini ve yazma ürünleriyle daha çok ilgilenmelerini sağlar. Bu durum öğrencilerin daha nitelikli yazılar yazmalarına yardımcı olur ve yazmaya ilişkin tutumlarını olumlu yönde etkiler.

Öğrencilere etkili yazma becerisi kazandırmak ve bu süreçte öğrencilerin yazmaya ilişkin olumlu tutum geliştirmelerine yardımcı olmak, öğretmenlerin eğitim-öğretim sürecindeki en önemli başarılarından biridir. Öğretmenlerin bu süreçte başarılı olma durumları, onların yazılı anlatım becerileri ve yazmaya ilişkin algıları ile yakından ilişkilidir (Dempsey, Pytlik Zillig ve Bruning, 2009). Çünkü yazma becerisi için ortaya koydukları performans ve yazılı ürünlerinin niteliği, öğretmen adaylarının o ana taşıdığı beceriler ile yakından ilgilidir. Bunun yanı sıra öğretmenlerin, çoğu zaman öğretmen eğitimi sırasında yazma öğretimi ile ilgili yeterli eğitimi almamış olmaları da onların sınıftaki yazma öğretim süreçlerini etkiler (Dempsey, Pytlik Zillig ve Bruning, 2009). Mevcut alan yazın, öğrencilerin yazma becerilerinin nasıl geliştirileceği ve bu süreçte hangi yöntem-tekniklerin kullanılabileceği konusunda öğretmen yetiştirme programlarının yetersiz olduğunu ortaya koymaktadır (Fry ve Griffin, 2010). Öğretmen 
yetiştirme programlarında, öğretmen adaylarının yazma yeterliliklerinin gelişimi çok önemlidir. Çünkü etkili bir şekilde dinleyen, konuşan, okuyan ve yazan bir öğretmen öğrencilerine de bu alanlarda rol model olacaktır (Martinez ve Strong, 1994).

Illkokul düzeyinde öğrencilerin yazılı anlatım becerilerini ve yazmaya ilişkin tutumlarını geliştirecek olan öğretmenlerin yazma sürecine yönelik yeterli deneyime ve bilgi birikimine sahip olmaları gerekmektedir. Fry ve Griffin'e (2010) göre alan yazındaki bazı yaklaşımlar, öğrencilere nasıl yazma öğretileceği ve onların yazma becerilerini nasıl anlamlı hale getirilebileceği konusunda öğretmen adaylarına yardımcı olur. Bu çalışmalardan biri de iş birlikli yazma çalışmalarıdır. Öğretmen eğitimi sırasında iş birliğine yönelik yapılan çalışmalar, öğretmen adaylarının iş birliğinin doğasını anlamaya ve iş birliğinin ne kadar etkili olduğunu gözlemlemelerine olanak tanır (Hughes, Parker-Katz ve Balasubramanian, 2013).

Yapılan bu araştırma, öğretmen adaylarının yazma becerilerinin ve yazmaya ilişkin tutumlarının geliştirilmesi ve bu bağlamda iş birlikli yazma çalışmalarından yararlanılması açısından önem kazanmaktadır. Ayrıca araştırma, öğretmen yetiştirme programlarında öğretmen adaylarının yazma becerilerinin ve yazmaya ilişkin tutumlarının nasıl geliştirileceği konusunda yol gösterici olacaktır. Bununla birlikte ülkemizde, iş birlikli yazma yönteminin yazma becerisine ve tutumuna etkisini inceleyen araştırmaların sayısı oldukça azdır. Öğretmen adaylarının yazma becerilerinin geliştirilmesine yönelik olarak bu tür deneysel çalışmaların yapılması gerekmektedir. Bu önemden hareketle yapılan çalışmanın amacı, iş birlikli yazma etkinliklerinin sınıf öğretmeni adaylarının yazma becerilerine ve yazmaya ilişkin tutumlarına etkisini belirlemektir. Araştırmada bu amaca ulaşmak için aşağıdaki sorulara yanıt aranmıştır:

1. Sınıf öğretmeni adaylarının "Yazma Becerisi Değerlendirme Formu"ndan aldıkları ön test ve son test puanları arasında istatistiksel olarak anlamlı bir fark var mıdır?

2. Sınıf öğretmeni adaylarının "Yazma Tutum Ölçeği"nden aldıkları ön test ve son test puanları arasında istatistiksel olarak anlamlı bir fark var mıdır?

\section{YÖNTEM}

\subsection{Araştırmanın Deseni}

Araştırmada "tek grup ön test-son test deneysel desen" kullanılmıştır. Bu desende deneysel işlemin etkisi tek bir grup üzerinde yapılan çalışmayla test edilir. Deneklerin bağımlı değişkene ilişkin ölçümleri uygulama öncesinde ön test, sonrasında son test olarak aynı denekler ve aynı ölçme araçları kullanılarak elde edilir (Büyüköztürk ve diğerleri, 2013). Araştırmada tek grup oluşturulduğu için bu desenden yararlanılmıştır. Araştırmada elde edilen verilerin toplanması, analizi ve yorumlanmasında nicel araştırma yönteminden yararlanılmıştır. Bu bağlamda araştırmada sınıf öğretmeni adaylarının uygulama öncesinde ve sonrasında yazma becerileri ve yazmaya ilişkin tutumları ilgili ölçme araçları kullanılarak belirlenmiştir.

\section{2. Çalışma Grubu}

Araştırmaya Karadeniz Teknik Üniversitesi Sınıf Öğretmenliği Ana Bilim Dalında 2. sınıfta öğrenim görmekte olan 28 öğretmen adayı katılmıştır. Araştırmaya katılan öğretmen adayları Sınıf Öğretmenliği Ana Bilim Dalında yürütülen "Cümle ve Metin Bilgisi" dersini alan 132 öğrenci arasından belirlenmiştir. Araştırmacı tarafından adaylara çalışmanın amacı ve içeriğiyle ilgili bilgi verilmiştir. Öğretmen adaylarına kimlerin çalışmaya katılmak istediği sorulmuştur. 28 öğretmen adayı, çalışmaya katılmak istediğini belirtmiştir. Bu öğretmen adaylarından bir grup oluşturulmuştur. Yani araştırmaya katılan öğretmen adayları gönüllülük esasına göre belirlenmiştir. Araştırmaya katılan öğretmen adaylarından 21'i kadın, 7'si erkektir. 


\subsection{Veri Toplama Araçları}

Araştırmada sınıf öğretmeni adaylarının yazma becerileri Erdoğan (2013) tarafından geliştirilen "Yazma Becerisi Değerlendirme Formu"yla değerlendirilmiştir. Yazma Becerisi Değerlendirme Formunda; yazı düzeni boyutunda 6, içerik boyutunda 7 ve dil ve anlatım boyutunda 8 olmak üzere toplam 21 madde yer almaktadır. Formda bu maddeler "zayıf (1)", "kabul edilebilir (2)", "orta (3)", "iyi (4)" ve "çok iyi (5)" olmak üzere beş düzeyde derecelendirilmektedir. Formun yazı düzeni alt boyutu Cronbach Alfa güvenirlik katsayısı. 92, içerik alt boyutu. 89 ve dil ve anlatım boyutu ise. 94 olarak bulunmuştur.

Araştırmada öğretmen adaylarının yazma becerisine ilişkin tutumlarını belirlemek için Erdoğan (2013) tarafından geliştirilen "Yazma Tutum Ölçeği" kullanılmıştır. Yazma Tutum Ölçeğinde, toplam 18 tutum ifadesi yer almaktadır. Bu maddelerden 10'u olumlu, 8'i ise olumsuz maddelerdir. Ölçekteki maddeler "Tamamen Katılıyorum, Katılıyorum, Kararsızım, Katılmıyorum ve Hiç Katılmıyorum" şeklinde beşli derecelendirilmekte ve puanlanmaktadır. Ölçekten elde edilebilecek en düşük puan 18, en yüksek puan ise 90 'dır. Yapılan analizler sonucunda Yazma Tutum Ölçeğinin Cronbach Alfa güvenirlik katsayısı .92 olarak hesaplanmıştır.

\subsection{Uygulama Süreci}

Araştırmada sınıf öğretmeni adaylarına iş birlikli yazma etkinlikleri yaptırılmıştır. Yaptırılan etkinlikler araştırmacı tarafından hazırlanmış ve uygulanmıştır. Uygulama, 8 hafta boyunca haftada 2 saat olmak üzere toplam 16 saat sürmüştür. Uygulamalar, süreç temelli yazma öğretimine uygun olarak gerçekleştirilmiştir. Bunun için yazma öncesi, taslak yazma, gözden geçirme, düzenleme ve yayımlama aşamalarına yer verilmiştir. Yazma öncesinde öğretmen adaylarının konu ile ilgili ön bilgilerinin ortaya çıkması için oyun oynama, beyin fırtınası, video izleme, fotoğraf inceleme, canlandırma, şarkı söyleme, salkım oluşturma gibi çeşitli etkinlikler yaptırılmıştır. Taslak yazma aşamasında öğretmen adaylarından ilgili türe yönelik iş birlikli olarak yazılar yazmaları istenmiştir. Gözden geçirme ve düzenleme aşamalarıyla yazıya son şekli verildikten sonra yayımlama aşamasında çeşitli etkinlikler ile yazılar sınıfla paylaşılmışır. Araştırmanın uygulama süreci şu şekilde açıklanabilir:

1. Hafta: Ön testlerin yapılması

2. Hafta: Hikâye

- Yazma öncesi: Nesnelerle ilgili oyun oynanması, nesnelerin içinde geçtiği resim yapılması

- Taslak yazma: İ̧ birlikli olarak nesnelerden yola çıkarak hikâye yazılması

- Gözden geçirme: Hikâyelerin içerik açısından düzenlenmesi

- Düzenleme: Hikâyelerin biçimsel açıdan düzenlenmesi

- Yayımlama: Hikâyelerin anlatı tekniğiyle paylaşılması

1. Hafta: Masal

- Yazma öncesi: Masala yönelik canlandırma yapılması, masal apartmanı oluşturulması, masal kahramanlarının apartmandaki sorunlarının canlandırılması, apartman toplantısı yapılması, apartmana gelen mektubun okunması

- Taslak yazma: Iş̧ birlikli olarak olayların sonrasına ilişkin masal yazılması

- Gözden geçirme: Masalların içerik açısından düzenlenmesi

- Düzenleme: Masalların biçimsel açıdan düzenlenmesi

- Yayımlama: Masalların sözel olarak paylaşılması

2. Hafta: Şiir

- Yazma öncesi: Şiire yönelik zihin haritası oluşturulması, şiire yönelik canlandırmalar yapılması, çağrışım çalışması yapılması 
- Taslak yazma: İş birlikli olarak kavramlardan yola çıkarak şiir yazııması

- Gözden geçirme: Şiirlerin içerik açısından düzenlenmesi

- Düzenleme: Şiirlerin biçimsel açıdan düzenlenmesi

- Yayımlama: Şiirlerin dinleti şeklinde paylaşılması

3. Hafta: Mektup

- Yazma öncesi: Gazete haberinin okunması, beyin fırtınası tekniğinin uygulanması, habere ilişkin röportaj yapılması, habere ilişkin canlandırma yapılması, haber bülteni hazırlanması

- Taslak yazma: İş birlikli olarak kahramana mektup yazılması

- Gözden geçirme: Mektupların içerik açısından düzenlenmesi

- Düzenleme: Mektupları biçimsel açıdan düzenlenmesi

- Yayımlama: Mektupların paylaşılması

4. Hafta: Fabl

- Yazma öncesi: Farklı fabllarla ilgili videolar izlenmesi, farklı fabllarla yönelik canlandırmalar yapılması, slogan yazılması

- Taslak yazma: Üç fabı kahramanının geçtiği yeni bir fablın iş birlikli olarak yazılması

- Gözden geçirme: Fablların içerik açısından düzenlenmesi

- Düzenleme: Fablların biçimsel açıdan düzenlenmesi

- Yayımlama: Fablların canlandırmalarla paylaşılması

5. Hafta: Gezi Yazısı

- Yazma öncesi: Farklı yerlere ilişkin fotoğrafların incelenmesi, yerlere ilişkin salkım oluşturulması, şarkı oluşturulması ve söylenmesi, donuk imgeler oluşturulması, gezgine yönelik canlandırmalar yapılması

- Taslak yazma: Gezginin yazdığı gezi yazısının iş birlikli olarak yazılması

- Gözden geçirme: Gezi yazısının içerik açısından düzenlenmesi

- Düzenleme: Gezi yazısının biçimsel açıdan düzenlenmesi

- Yayımlama: Gezi yazısının televizyon programı şeklinde paylaşılması

6. Hafta: Otobiyografi

- Yazma öncesi: Kahraman yönelik bilinç koridoru tekniğinin uygulanması, kahramanın resminin yapılması, yaşamına yönelik canlandırmalar yapılması

- Taslak yazma: Kahramanın otobiyografisinin iş birlikli olarak yazııması

- Gözden geçirme: Otobiyografi yazısının içerik açısından düzenlenmesi

- Düzenleme: Otobiyografi yazısının biçimsel açıdan düzenlenmesi

- Yayımlama: Otobiyografi yazısının paylaşılması

7. Hafta: Son testlerin yapılması

\subsection{Verilerin Toplanması ve Analizi}

Araştırmada sınıf öğretmeni adaylarının uygulamanın başında yazma becerilerini belirlemek için öğretmen adaylarına çeşitli yazma konuları ve türleri verilmiştir. Ayrıca onlardan da yazmak istedikleri konuları ve türleri söylemeleri istenmiştir. Belirlenen tüm yazma konuları ve türleri tahtaya yazılmıştır. Öğretmen adaylarından bu konu ve türler arasından birini seçerek bu konuyla ilgili yazı yazmaları istenmiştir. Uygulamanın sonunda da öğretmen adaylarından uygulamanın başında yazdıkları yazıyla aynı türde yazı yazmaları istenmiştir.

Öğretmen adaylarının uygulamanın başında ve sonunda yazdıkları yazılar "Yazma Becerisi Değerlendirme Formu"yla analiz edilmiştir. Öğretmen adaylarının uygulamanın başında ve sonunda "Yazma Becerisi Değerlendirme Formu"ndan aldıkları puanların aritmetik ortalamaları arasında istatistiksel olarak anlamlı bir fark olup olmadığı ilişkili iki ölçüm seti 
arasında farkın anlamlılı̆ının test edilmesi ile veri türü ve sayısının dikkate alınması nedeniyle "Wilcoxon İşaretli Sıralar Testi" ile analiz edilmiştir.

Araştırmada öğretmen adaylarının uygulamanın başında ve sonunda yazmaya ilişkin tutumlarını belirlemek için "Yazma Tutum Ölçeği" uygulanmıştır. Öğretmen adaylarının "Yazma Tutum Ölçeği”nden aldıkları puanlar arasında istatistiksel olarak anlamlı bir fark olup olmadığı yine aynı şekilde ilişkili iki ölçüm seti arasında farkın anlamlılığının test edilmesi ile veri türü ve sayısının dikkate alınması nedeniyle "Wilcoxon İşaretli Sıralar Testi" ile analiz edilmiştir.

\section{BULGULAR VE YORUMLAR}

\subsection{Birinci Araştırma Sorusuna Illişkin Bulgular ve Yorum}

Araştırmada öğretmen adaylarının "Yazma Becerisi Değerlendirme Formu"nun alt boyutlarından aldıkları ön test ve son test puanlarının ortalamaları arasında anlamlı bir fark olup olmadığı "Wilcoxon İşaretli Sıralar Testi" ile analiz edilmiştir. Öğretmen adaylarının aldıkları puanların ortalamaları arasında anlamlı bir fark olup olmadığına ilişkin sonuçlar Tablo 1 'de verilmiştir.

Tablo 1

Sınıf Öğretmeni Adaylarının "Yazma Becerisi Değerlendirme Formu" Alt Boyutlarından Aldıkları Ön Test ve Son Test Puanlarının Wilcoxon Iş̧aretli Sıralar Testi Sonuçları

\begin{tabular}{cccccc}
\hline Yazı Düzeni (Son test-Ön test) & $\mathbf{n}$ & Sıra ortalaması & Sıra toplamı & $\mathbf{z}$ & $\mathbf{p}$ \\
\hline Negatif Sıra & 0 & .00 & .00 & $4.48^{*}$ & .000 \\
Pozitif Sıra & 26 & 13.50 & 351.00 & & \\
Eşit & 2 & - & - & & \\
\hline Içerik (Son test-Ön test) & & & & & \\
\hline Negatif Sıra & 0 & .00 & .00 & $4.29^{*}$ & \\
Pozitif Sıra & 24 & 12.50 & 300.00 & & \\
Eşit & 4 & - & - & & \\
\hline Dil ve Anlatım (Son test-Ön test) & & & .000 \\
Negatif Sıra & 0 & .00 & 325.00 & & \\
Pozitif Sıra & 25 & 13.00 & - & & \\
Eşit & 3 & - & & &
\end{tabular}

*Negatif sıralar temeline dayalı

Tablo 1'deki veriler incelendiğinde, sınıf öğretmeni adaylarının uygulama öncesinde ve sonrasında "Yazma Becerisi Değerlendirme Formu" yazı düzeni, içerik ile dil ve anlatım alt boyutlarından aldıkları puanlar arasında istatistiksel olarak anlamlı bir fark olduğu görülmektedir $(p<.05)$. Fark puanlarının sıra ortalaması ve toplamları dikkate alındığında gözlenen bu farkın pozitif sıralar yani son test puanları lehine olduğu görülmektedir. Araştırmada elde edilen bu bulgu, iş birlikli yazma etkinliklerinin sınıf öğretmeni adaylarının yazı düzeni, içerik ile dil ve anlatım açısından yazma becerilerini geliştirdiğini ortaya koymaktadır.

\section{2. İkinci Araştırma Sorusuna iliş̧in Bulgular ve Yorum}

Araştırmada sınıf öğretmeni adaylarının uygulama öncesinde ve sonrasında "Yazma Tutum Ölçeği"nden aldıkları ön test ve son test puanlarının ortalamaları arasında anlamlı bir fark olup olmadığı "Wilcoxon İşaretli Sıralar Testi" ile analiz edilmiştir. Öğretmen adaylarının aldıkları puanların ortalamaları arasında anlamlı bir fark olup olmadığına ilişkin sonuçlar Tablo 2'de sunulmuştur. 
Tablo 2

Sınıf Öğretmeni Adaylarının "Yazma Tutum Ölçeği"nden Aldıkları Ön Test ve Son Test Puanlarının Wilcoxon Işaretli Sıralar Testi Sonuçları

\begin{tabular}{cccccc}
\hline Tutum (Son test-Ön test) & $\mathbf{n}$ & Sıra ortalaması & Sıra toplamı & $\mathbf{z}$ & $\mathbf{p}$ \\
\hline Negatif Sıra & 0 & .00 & .00 & $4.54^{*}$ & .000 \\
Pozitif Sıra & 27 & 14.00 & 378.00 & & \\
Eşit & 1 & & & & \\
\hline
\end{tabular}

*Negatif sıralar temeline dayalı

Tablo 2'ye göre, sınıf öğretmeni adaylarının uygulama öncesinde ve sonrasında "Yazma Tutum Ölçeği"nden aldıkları puanlar arasında istatistiksel olarak anlamlı bir fark olduğu görülmektedir $(p<.05)$. Fark puanlarının sıra ortalaması ve toplamları dikkate alındığında bu farkın pozitif sıralar yani son test puanları lehine olduğu görülmektedir. Araştırmada elde edilen bu bulgu, iş birlikli yazma etkinliklerinin, adayların yazmaya ilişkin tutumlarını olumlu etkilediğini ortaya koymaktadır.

\section{SONUÇ, TARTIŞMA VE ÖNERILER}

$\mathrm{Bu}$ araştırmada iş birlikli yazma etkinliklerinin sınıf öğretmeni adaylarının yazma becerilerine ve yazmaya ilişkin tutumlarına etkisi belirlenmiştir. Araştırmada elde edilen sonuçlar, iş birlikli yazma etkinliklerinin sınıf öğretmeni adaylarının yazma becerilerini geliştirdiğini ortaya koymaktadır. İş birlikli yazma, öğrencileri yazdıkları yazılar üzerinde düşünmeye, tartışmaya ve karşılaştıkları dilsel sorunları çözmek üzere ortaklık yapmaya itmektedir (Dobao, 2012). Bu sayede gruplardaki öğrencilerin kendi düşüncelerini özgürce paylaşabildikleri, üzerinde tartışabildikleri ve birbirlerinin düşüncelerini yapılandırabildikleri bir etkileşim ortamı oluşmuş olur. Gruplardaki öğrencilerin sürekli düşünmelerine olanak sağlayan bu etkileşim ortamı, farklı düşüncelerin ortaya çıkmasına, eksik düşüncelerin tamamlanmasına ve yeni düşüncelerin zenginleştirilmesinde yardımcı olur (Ferguson-Patrick, 2007; Fung, 2010; Storch, 2005; Shehadeh, 2011; Vass, 2007). Sınıf öğretmeni adayları ile yapılan iş birlikli yazma çalışmalarında grup üyeleri yazı yazmadan önce ve yazma sırasında konu ile ilişkili grup içerisinde konuşmalar ve tartışmalar yapmışlardır. Bu etkileşim ve iletişim ortamı, grup üyelerinin derinlemesine düşünmelerine olanak sağlamış olabilir. Başka bir ifadeyle, iş birlikli çalışma ile yazılacak konu hakkında detaylı düşünme fırsatı yakalandığı ve sınıf öğretmeni adaylarının değişik fikirler üretmelerine imkân verildiği düşünülmektedir. Çünkü Prior’a (2006) göre yazma, diyaloğa dayalı bir keşif sürecidir. İş birliği sırasında kurulan diyaloglar sayesinde grupla yazılan yazılar, bireysel yazılan yazılara oranla daha iyi bir performans sergiler (Swain, 2000). Buradan hareketle iş birlikli yazma sürecinde grup üyelerinin yazma sürecinde etkileşim halinde olmalarının ve yazma konusu ile ilgili birbirlerinin düşünme süreçlerini gözlemlemelerinin, öğrencilerin yazılı anlatım becerilerinin gelişiminde etkili olduğu söylenebilir.

Graham ve Perin'e (2007) göre iş birlikli yazma, yazının kalitesini olumlu yönde etkileyen ve grup üyelerinin bir takım olarak konuyu seçme, planlama, yazma, gözden geçirme ve düzenleme aşamalarında birbirlerine yardım ettikleri bir çalışmadır. Çünkü iş birlikli yazma, takım çalışması kavramını etkili bir şekilde öğretir. Bu takım çalışması içinde her öğrenci kendi güçlü yönlerini ortaya koyar ve böylece ortaya koyulan yazının niteliği artar (Hernandez ve diğerleri 2010; Jones, Jones ve Murk, 2012). Bu araştırmada, sınıf öğretmeni adaylarının iş birlikli yazma sürecinde birbirlerinden sürekli dönüt aldıkları gözlemlenmiştir. Çalışma sırasında grup üyelerinin üstün yönlerini ortaya koydukları ve birbirlerinin eksik yönlerini tamamladıkları görülmüştür. Ayrıca bu takım çalışması içerisinde tek başına fikir üretmek durumunda kalmamışlardır. Akıllarına bir fikir gelmediği zaman, gruptaki diğer arkadaşlarıyla görüş alışverişinde bulunmuşlardır. Bu durum, grup hâlinde yazı yazan öğrencilerin, bireysel olarak 
yazı yazan öğrencilere oranla dil bilgisi yetkinliği ve karmaşıklığı daha yüksek olan metinleri nasıl üretebildiklerini de açıklamaktadır (Storch, 2005). Bu bağlamda, iş birlikli yazma çalışmalarının katılımcıların yazı düzeni, içerik, dil ve anlatım açısından yazma becerilerini geliştirdiği ortaya çıkmaktadır.

Öğrencilerin yazılı anlatım becerilerinin gelişiminde önemli rol oynayan bir diğer etken ise yazma öncesi aşamada yapılan yazmaya hazırlık çalışmalarıdır. Yazmaya zihinsel olarak hazırlanan ve yazılacak konu ile ilgili ön bilgileri harekete geçirilen öğrenciler, kendilerini yazılı olarak etkili bir şekilde ifade edebilirler. McCutchen, Covill, Hoyne ve Mildes'e (1994) göre yazılacak konuya ilişkin ön bilgiler, yazının niteliğini belirleyen önemli bir etkendir. Bu araştırmada, yazma öncesi aşamada grup üyelerinin ön bilgilerini harekete geçirmek için konu ile ilgili çeşitli etkinlikler yapılmıştır. Buradan hareketle, iş birlikli yazma etkinlikleri sürecinde yer verilen yazma öncesi aşama ile adayların ön bilgilerinin harekete geçirilmesinin ve bilişsel olarak yazmaya hazırlanmalarının, yazma becerilerini geliştirdiği söylenebilir.

Araştırmada sınıf öğretmeni adaylarına yaptırılan iş birlikli yazma çalışmalarında, süreç temelli yazma aşamaları uygulanmıştır. Buna göre yazma sürecinde; yazma öncesi, taslak yazma, gözden geçirme, düzenleme ve yayımlama aşamalarına yer verilmiştir. Süreç temelli yazmada, yazma öncesi aşamada öğrencilerin konu hakkında ön bilgileri ortaya çıkarılmış ve yazmaya duyuşsal ve bilişsel olarak hazır hale gelmeleri sağlanmıştır. Taslak yazma aşamasında, öğrencilerin duygu ve düşüncelerini diledikleri şekilde yazıya dökmeleri sağlanmıştır. Ayrıca öğrencilere hiç kimsenin yazısının çok iyi olmadığı hatırlatılarak taslak olarak yazılan yazıların daha sonra düzeltileceği söylenmiştir. Gözden geçirme aşamasında ise yazdıkları taslakları anlam bağlamında incelemeleri istenmiştir. Bunun için çıkarılması gereken yerleri çıkarmaları, eklenmesi gereken cümleleri eklemeleri ya da bazı paragrafları yeniden düzenlemeleri gerektiği vurgulanmıştır. Yazılarını içerik olarak inceleyen öğrencilere daha sonra dil bilgisi, noktalama ve yazım kuralları açısından düzeltmeler yapmaları söylenmiştir. Son olarak yayımlama aşamasında da yazılan yazılar, farklı etkinlikler ile sınıfla paylaşılmıştır. Yazma sürecinin bu şekilde aşamalara uygun olarak yürütülmesi, öğrencilerin yazma becerilerinin gelişiminde oldukça önemli bir rol oynar (Bright, 2007; Bruning ve Horn, 2000; Dorn ve Soffos, 2001; Graham ve Sandmel, 2011; Karatay, 2011; Nauman 2007). Yapılan araştırmada da bu aşamalara yönelik çalışmalara yer verilmesinin, öğrencilerin yazıya aktarmak istediklerini amacına uygun şekilde ifade edebilmelerinde etkili olduğu görülmektedir.

Araştırmadan elde edilen bu bulgu, iş birlikli yazma çalışmalarının öğrencilerin yazılı anlatım becerilerinin gelişiminde etkili olduğunu göstermektedir. Araştırmadan elde edilen bu sonuç, konu ile ilgili yapılan bazı araştırmaların sonuçlarıyla da tutarlılık göstermektedir (Dobao, 2012; Fry ve Griffin, 2010; Shehadeh, 2011;).

Araştırmada elde edilen sonuçlar, iş birlikli yazma çalışmalarının sınıf öğretmeni adaylarının yazmaya ilişkin tutumlarını olumlu yönde etkilediğini ortaya koymaktadır. Sınıf öğretmeni adaylarının yazmaya ilişkin tutumlarının gelişmesinde, yapılan çalışmaların niteliği önemli bir rol oynar. McDonough'a (2004) göre iş birlikli şekilde yapılan yazma çalışmaları, kendini henüz yazılı anlatım konusunda yeterli görmeyen ve yazmayı sevmeyen öğrenciler için iyi bir başlangıçtır. Çünkü ikili ya da büyük grup etkinlikleri öğrencilere kendi kendine çalışma bağımsız çalışma imkânı sağlar. Bu sırada öğrenciler daha az kaygılı olurlar ve kendilerini daha çok güvende hissederler. Lambirth ve Goouch'a (2006) göre öğrencilere yazma çalışmaları için grupla çalışma fırsatı verilmesi onları yazmaya daha çok güdüler. Ayrıca grupça yazılan yazılarda öğrencilerin birbirlerine destek olmaları ve eksik oldukları noktaları birlikte tamamlamaları, yazma sürecini açık bir şekilde gözlemlemelerine ve bu sürecin üstesinden tek başlarına da gelebileceklerine olan inançlarının artmasına olumlu katkısı vardır (Erdoğan, 2012). Buradan hareketle iş birlikli yazma etkinlikleri ile grup şeklinde yazma çalışmaları 
yapılmasının, öğrencilerin yazmaya ilişkin olumlu tutum geliştirmelerinde etkili olduğu görülmektedir.

Bruning ve Horn'a (2000) göre sınıfta yazmaya ilişkin olumlu bir atmosferin yaratılması öğrencileri yazı yazmaya daha çok güdüler. Sınıf öğretmeni adayları ile yapılan iş birlikli yazma etkinliklerinde, öğrencilere öncelikle duygu ve düşüncelerini özgür bir biçimde ifade edebilecekleri söylenmiştir. Yazdıkları yazıların içeriklerine ve uzunluklarına karışılmayacağı ifade edilmiştir. Bununla birlikte sınıf ortamında sınıf öğretmeni adaylarının yazdıkları yazılar olumsuz yönde eleştirilmemiş aksine desteklenmiştir. İş birlikli yazma sürecinde, grup çalışması sayesinde her bir grup üyesinin çekinmeden birbirlerine konu ile ilişkili düşüncelerini özgürce ifade edebilmeleri sağlanmıştır. Sınıf arkadaşlarına daha rahat bir şekilde fikirlerini aktarabilmeleri özgür bir eğitim ortamı oluşturulmasına yardımcı olmuştur. Grup üyelerinin birbirleri arasında yaptıkları bu sosyal etkileşimler, yazma sürecinde olumlu bir atmosferin yaratılmasına katkı sağlamıştır. İs birlikli yazma çalışmaları ile sınıfta oluşturulan bu atmosferin, öğrencilerin yazmaya yönelik olumlu tutum geliştirmelerinde etkili olduğu söylenebilir.

Iş birlikli yazma çalışmaları sonunda yayımlama aşamasına yer verilmiştir. Yazılan yazıların paylaşılması öğrencilerin yazılarına değer verildiğini fark etmelerine ve böylece eğlenmelerine olanak sağlar (Archibald, 2010). Bununla birlikte öğrenciler kendi yazılarının basıldığını gördüklerinde kendilerini gerçek bir yazar olarak görürler ve bu durum öğrencilerin yazmaya ilişkin tutumlarını olumlu yönde etkiler (Nauman, 2007). Yapılan araştırmada da süreç temelli yazma sürecinin sonunda gruplara, kendi çalışmalarını yayımlamalarına olanak sağlayan çeşitli etkinlikler yaptırımıştır. Bunun için gazete/dergi oluşturma, yazılan yazılar mektup ile gönderilme, panolarda sergileme vb. etkinliklere yer verilmiştir. Buradan hareketle iş birlikli yazma sürecinde yer verilen yayımlama çalışmalarının öğrencilerin yazmaya olan ilgi ve isteklerini geliştirmede etkili olduğu ortaya çıkmaktadır.

Araştırmadan elde edilen bu bulgu, iş birlikli yazma çalışmalarının öğrencilerin yazmaya ilişkin tutumlarını geliştirmede etkili olduğunu göstermektedir. Araştırmadan elde edilen bu sonuç, bazı araştırmaların sonuçlarıyla tutarlılık göstermektedir (Humphris, 2010; Sutherland ve Topping, 1999; Yarrow ve Topping, 2001).

Yazma, kendi içinde birçok beceriyi barındırdığı için öğrencilerin yazma becerilerini geliştirmek zordur. Bunun için öncelikle sınıf öğretmeni adaylarının hizmet öncesinde yazma becerilerini geliştirmeye yönelik çeşitli yöntem-tekniklerin uygulamalı olarak öğretilmesine intiyaç vardır. Buradan hareketle yapılan araştırmada iş birlikli yazma etkinliklerinin sınıf öğretmeni adaylarının yazma becerilerini geliştirdiği ve yazmaya ilişkin tutumlarını olumlu yönde etkilediği sonuçlarına ulaşılmıştır. Araştırmada elde edilen bu sonuçlar ışığında, sınıf öğretmeni yetiştirme sürecine yönelik şu öneriler getirilebilir:

1. Sınıf öğretmeni adaylarına lisans eğitimlerinde yazma öğretimi sırasında iş birlikli yazma çalışmaları yaptırılmalıdır.

2. Sınıf öğretmenliği lisans programlarına iş birlikli yazma ve yazma becerisiyle ilgili seçmeli dersler konulmalıdır.

\section{KAYNAKLAR}

Anılan, H., Akkuş, R., ve Acar, D. (2009). İşbirlikli yazma çalışmalarının ilköğretim üçüncü sınıf öğrencilerinin yazma başarılarına etkisi 8. Ulusal Sınıf Öğretmenliği Sempozyumunda sunulmuş bildiri, Eskişehir.

Archibald, M. (2010). Perceptions of diverse first-grade learners of their writing instruction and growth as writers. Doctoral of dissertation, Walden University. 
Bright, R. (2007). Write through the grades: Teaching writing in secondary schools, Canada: Portage Main Press.

Bruning, R. ve Horn, C. (2000). Developing motivation to write. Educational Psychologist, 35 (1), 25-37.

Büyüköztürk, Ş., Çakmak, E. K., Akgün, Ö. E., Karadeniz, Ş. ve Demirel, F. (2013). Bilimsel araştırma yöntemleri. Ankara: Pegem A Akademi.

Cutler, L. ve Graham, S. (2008). Primary grade writing instruction: A national survey. Journal of Educational Psychology, 100 (4), 907-919.

Dempsey, M. S., PytlikZillig, L. M. ve Bruning, R. H. (2009). Helping preservice teachers learn to assess writing:Practice and feedback in a Web-based environment. Assessing Writing, 14, 38-61.

De Smedt, F. ve Van Keer, H. (2014). A research synthesis on effective writing instruction in primary education. Procedia - Social and Behavioral Sciences, 112, 693 - 701. International Conference on Education \& Educational Psychology.

Dobao, A. F. (2012). Collaborative writing tasks in the L2 classroom: Comparing group, pair, and individual work. Journal of Second Language Writing, 21 (1), 40-58.

Dobao, A. F. ve Blum, A. (2013). Collaborative writing in pairs and small groups: Learners' attitudes and perceptions. System, 41, 365-378.

Dorn, L. J. ve Soffos, C. (2001). Scaffolding young writers. America: Stenhouse Publishers.

Dyson, A. H. (1995). Writing children: Reinventing the development of childhood literacy. Written Communication, 12 (1), 4-46.

Erdoğan, Ö. (2012). Süreç temelli yaratıcı yazma uygulamalarının yazılı anlatım becerisine ve yazmaya ilişkin tutuma etkisi. Yayınlanmamış doktora tezi, Hacettepe Üniversitesi, Sosyal Bilimler Enstitüsü, Ankara.

Erdoğan, T. (2013). The effect of creative drama method on pre-service classroom teachers' writing skills and attitudes towards writing. Australian Journal of Teacher Education, 38 (1), 44-61.

Ferguson-Patrick, K. (2007). Writers develop skills through collaboration: an action research approach, Educational Action Research, 15:2, 159-180.

Fletcher, R. ve J. Portalupi. (2001). Writing workshop: The essential guide. Portsmouth, NH: Heinemann.

Fry, S. W. ve Griffin, S. (2010). Fourth Graders as Models for Teachers: Teaching and Learning $6+1$ Trait Writing as a Collaborative Experience, Literacy Research and Instruction, 49:4, 283-298.

Fung, Y. M. (2010). Collaborative writing features. RELC Journal, 41 (1), 18-30.

Graham, S. ve Perin, D. (2007). Writing next: Effective strategies to improve writing of adolescents in middle and high school. Washington, DC: Alliance for Excellent Education.

Graham, S. ve Sandmel, K. (2011). The process writing approach: A meta-analysis. The Journal of Educational Research, 104 (6), 396-407.

Graham, S., Berninger, V. ve Abbott, R. (2012). Are attitudes toward writing and reading separable constructs? A study with primary grade children. Reading \& Writing Quarterly, 28 (1), 51-69. 
Güneş, F. (2007). Türkçe öğretimi ve zihinsel yapılandırma. Ankara: Nobel Yayın.

Hernandez, N., Hoeksema, A. Kelm, H., Jefferies, J., Lawrence, K., Lee, S. ve Miller, P. (2010). Collaborative Writing in the Classroom: A Method to Produce Quality Work,http://www.edb.utexas.edu/cscl/2010/topicpapers/s2paper.pdf

Hughes, M. T.,Parker-Katz, M.ve Balasubramanian,A. (2013). Learning to teach literacy through collaborative discussions of student work, Teachers andTeaching: theory and practice, 19:5, 543-558.

Humphris, R. (2010). Developing students as writers through collaboration. Changing English, 17 (2), 201-214.

Jones, D. L., Jones, J. W. ve Murk, P. J. (2012). Writing collaboratively: Priority, practice and process. Adult Learning, 23 (2), 90-93.

Kahn, J. M. ve Holody, R. (2012). Supporting field instructors' efforts to help students improve writing. Journal of Social Work Education, 48 (1), 65-73.

Karatay, H. (2011). Süreç temelli yazma modelleri: Planlı yazma ve değerlendirme, Yazma Eğitimi, M. Özbay (Ed.), Ankara: Pegem A Akademi.

Karsbaek, B. (2011). Writer's workshop: Does it improve the skills of young writers?,Illinois Reading Council Journal, 39 (2), 3-11.

Kolb, K.H., Longest, K. C. ve Jensen, M. J. (2013). Assessing the writing process: Do writingintensive first-year seminars change how students write?,Teaching Sociology, 41(1) 2031.

Lambirth, A. ve Goouch, K. (2006). Golden times of writing: The creative compliance of writing journals. Literacy, 40 (3), 146-152.

Lin, O. P. ve Maarof, N. (2013). Collaborative Writing in Summary Writing: Student Perceptions and Problems. Procedia - Social and Behavioral Sciences 90, 599-606. 6th International Conference on University Learning and Teaching.

Lowry, P. B., Curtis, A., ve Lowry, M. R. (2004). Building a taxonomy and nomenclature of collaborative writing to improve interdisciplinary research and practice. Journal of Business Communication, 41(1), 66-99.

Lundstrom, K. ve Baker, W. (2009). To give is better than to receive: The benefits of peer review to the reviewer's own writing. Journal of Second Language Writing, 18 (1), 30-43.

Maden, S. (2011). Jigsaw I tekniğinin yazılı anlatım becerisi akademik başarısına etkisi. Kuram ve Uygulamada Eğitim Bilimleri, 11 (2): 901-917.

Martinez, I. ve Strong, W. (1994). Assessing Writing Competence in Teacher Education, Action in Teacher Education, 16 (2), 28-36.

McCarthey, S. J. ve Ro, Y. S. (2011). Approaches to writing instruction, Pedagogies: An International Journal, 6:4, 273-295.

McCutchen, D., Covill, A., Hoyne, S. H. ve Mildes, K. (1994). Individual differences in writing: Implications of translating fluency. Journal of Educational Psychology, 86 (2), 256-266.

McDonough, K. (2004). Learner-learner interaction during pair and small group activities in a Thai EFL context, System, 32 (2), 207-224. 
Miell, D. ve Littleton, K. (2008). Musical collaboration outside school: Processes of negotiation in band rehearsals. International Journal of Educational Research, 47 (1), 41-49.

Muschla, C. R. (2006). Teach terrific writing. New York: McGraw Hill.

Nauman, A. D. (2007). Writing in the primary grades: Tapping young children's enthusiasm to help them become good writers. Illinois Reading Council Journal,35 (4), 16-28.

Olinghouse, N. G. ve Santangelo, T. (2010). Assessing the writing of struggling learners. Focus On Exceptional Children, 43 (4), 1-27.

Olive, T. (2004). Working memory in writing: Empirical evidence from the dual-task technique. The European Psychologist, 9 (1), 32-42.

Phielix, C., Prins, F.ve Kirschner, P. A. (2010). Awareness of group performance in a CSCLenvironment: Effects of peer feedback and reflection. Computers in Human Behavior, 26, 151-161.

Prior, P. (2006). A sociocultural theory of writing. C.A. MacArthur, S.Graham ve J. Fitzgerald (Ed.), Handbook of writing research. New York: Guilford Press.

Sharples, M. (2003). How we write: Writing as creative design. London: Routledge.

Shehadeh, A. (2011). Effects and student perceptions of collaborative writing in L2. Journal of Second Language Writing, 20 (4), 286-305.

Storch, N. (2005). Collaborative writing: Products, process, and students' reflections. Journalof Second Language Writing, 14, 153-173.

Sundem, G. (2007). Improving student writing skills. USA: Corinne Burton.

Sutherland, J. A. ve Topping, K. J. (1999). Collaborative creative writing in eight year-olds: Comparing cross-ability fixed role and same-ability reciprocal role pairing. Journal of Research in Reading, 22 (2), 154-179.

Swain, M. (2000). The output hypothesis and beyond: Mediating acquisition through collaborative dialogue. In J. P. Lantolf (Ed.), Sociocultural theory and second language learning (pp. 97-114). Oxford, UK: Oxford University Press.

Topping, K., Nixon, J., Sutherland, J. ve Yarrow, F. (2000). Paired writing: A framework for effective collaboration. Reading, 34 (2), 79-89.

Topping, K., Smith, E., Swanson, I., ve Elliot, A. (2000). Formative peer assessment of academic writing between postgraduate students. Assessment and Evaluation in Higher Education, 25, 149-169.

Vass, E. (2007). Exploring processes of collaborative creativity-The role of emotions in children's joint creative writing. Thinking Skills and Creativity, 2 (2), 107-117.

Wigglesworth, G. ve Storch, N. (2012). What role for collaboration in writing and writing feedback, Journal of Second Language Writing, 21, 364-374.

Yang, L. (2014). Examining the mediational means in collaborative writing: Case studies of undergraduate ESL students in business courses. Journal of Second Language Writing, 23, 74-89.

Yarrow, F. ve Topping, K. J. (2001). Collaborative writing: The effects of metacognitive prompting and structured peer interaction. British Journal of Educational Technology, 71, 261-282. 


\section{SUMMARY}

Teachers who develop primary school students' writing expression skills and attitudes towards writing, should have enough experience and knowledge towards writing process. According to Fry and Griffin (2010), some approaches in the literature help the pre-service teachers about how to teach writing to students and how to make their writing skills become meaningful. One those approaches is the collaborative writing. Activities about collaboration during the teacher training provide pre-service teachers to understand the nature of collaboration and to observe the effectiveness of the collaboration (Hughes, Parker-Katz and Balasubramanian, 2013). Present study has become important in terms of the development of pre-service teachers' attitudes toward writing and in this regard, utilization of collaborative writing activities. Besides, this study would be a guide for the teacher training programs respecting how to develop the pre-service teachers' writing skills and attitudes toward writing. In addition to this, studies investigating the effect of the collaborative writing on the writing skill and attitude are quite a little in our country. This type of experimental studies related to development of writing skills of teacher candidates, is needed.

The aim of the study is to identify the effects of the collaborative writing activities on the preservice classroom teachers' attitudes toward the written expression skills and writing. In the study which is a single group design, pretest and post-test was employed. The study employed a quantitative method in regard to collection, analysis and discussion of the data of the study. The writings of the participants at the beginning and end of the study were evaluated through "Writing Skill Evaluation Form". "Writing Attitude Scale" was used as pre- and post-test to reveal the participants' attitudes towards writing. The participants of the study were 28 pre-service teachers who were attending second grade at the classroom teaching branch of the educational sciences faculty at Karadeniz Technical University. In the study, several collaborative writing activities were carried out with the participants. The activities were prepared and applied by the researcher. The application has been applied for eight weeks, two hours per week. Therefore, a total of 16 hours was allocated for the application.

The application was done respecting process based writing teaching. Therefore, draft writing, revising, editing and publishing stages were implemented before the writing. Besides, in order to reveal the prior knowledge of the teacher candidates about the topic, some activities such as playing game, brain storming, video watching, photograph analyzing, singing, clustering have done before the writing. In the draft writing stage, pre-service teachers were asked to collaboratively write about related type. After putting into final form of the writings with the revising and editing stages, writings were shared with some activities in the classroom in the publishing stage.

In order to determine the writing skills of the participants before and after the study, an evaluation form of writing skills was administered to them. In order to determine their attitudes towards writing before and after the study, the scale of writing attitudes was used. The findings of the study showed that collaborative writing activities improve the participants' writing skills and their attitudes towards writing.

In the light of the results of the study, these suggestions for primary school teacher training can be made;

1. Primary school pre-service teachers should have collaborative writing activities done during teaching writing in their undergraduate education.

2. Elective courses related with collaborative writing and writing skill should be placed into the primary school teaching undergraduate program. 